\title{
High expression of PU.1 is associated with Her-2 and shorter survival in patients with breast cancer
}

\author{
JING LIN ${ }^{1,2^{*}}$, WEI LIU ${ }^{3 *}$, TIAN LUAN ${ }^{1,2}$, LILI YUAN ${ }^{1,2}$, WEI JIANG ${ }^{4}$, HUILONG CAI $^{1,2}$, \\ WEIGUANG YUAN ${ }^{1,2}$, YUWEN WANG ${ }^{5}$, QINGYUAN ZHANG ${ }^{1,2,6}$ and LIHONG WANG ${ }^{1,2,7}$ \\ ${ }^{1}$ Department of Cytobiology, Institute of Cancer Prevention and Treatment, Harbin Medical University; \\ ${ }^{2}$ Department of Cytobiology, Heilongjiang Academy of Medical Sciences, Harbin, Heilongjiang 150081; \\ ${ }^{3}$ Department of Pathology, The First Affiliated Hospital of Harbin Medical University, Harbin, Heilongjiang 150001; \\ ${ }^{4}$ Department of Biomedical Mathematics, College of Bioinformatics Science and Technology, Harbin Medical University; \\ ${ }^{5}$ Department of Laboratory Diagnostics, The Second Affiliated Hospital of Harbin Medical University; ${ }^{6}$ Department of \\ Internal Medicine, The Third Affiliated Hospital of Harbin Medical University, Harbin, Heilongjiang 150081; \\ ${ }^{7}$ Department of Pathophysiology, Medical School of Southeast University, Nanjing, Jiangsu 210009, P.R. China
}

Received April 15, 2016; Accepted August 23, 2017

DOI: $10.3892 / 01.2017 .7204$

\begin{abstract}
The transcription factor PU.1 was previously identified as an oncogene or a tumor suppressor in different types of leukemia. The aim of the present study was to investigate the expression of PU.1 in breast cancer and to analyze its association with clinical features and prognosis. Immunohistochemistry was used to determine PU.1 expression in breast cancer tissue microarrays and paraffin-embedded sections. The association between PU.1 expression and clinicopathological factors was assessed by using chi-square test. The survival analysis of patients was conducted by using Kaplan-Meier analysis and log-rank tests. Cox regression was utilized for univariate and multivariate analyses of prognostic factors. The results indicated that the expression level of PU.1 protein in breast cancer samples was significantly higher compared with normal breast tissues $\left(\mathrm{P}=2.63 \times 10^{-8}\right)$. Furthermore, the level of PU.1 expression was detected to be positively associated with androgen receptor $(\mathrm{P}=0.027)$ and human epidermal growth factor receptor 2 status $\left(\mathrm{P}=2.03 \times 10^{-21}\right)$ as well as molecular subtype $\left(\mathrm{P}=3.51 \times 10^{-11}\right)$. Furthermore, patients with negative PU.1 expression had longer OR compared with those with positive PU.1 expression $\left(\mathrm{P}=3.67 \times 10^{-4}\right)$. Multivariate Cox regression analysis revealed that PU.1 expression level and
\end{abstract}

Correspondence to: Professor Lihong Wang or Professor Qingyuan Zhang, Department of Cytobiology, Institute of Cancer Prevention and Treatment, Harbin Medical University, 6 Baojian Road, Nangang, Harbin, Heilongjiang 150081, P.R. China E-mail: 1w2247@yeah.net

E-mail: 13313612989@163.com

*Contributed equally

Key words: breast cancer, PU.1, human epidermal growth factor receptor 2, overall survival, prognosis tumor-node-metastasis stage were independent prognostic factors for overall survival $(\mathrm{P}=0.034$ and $\mathrm{P}=0.018$, respectively). Therefore, PU.1 protein expression may contribute to breast cancer progression and may be a valuable molecular marker to predict the prognosis of patients with breast cancer.

\section{Introduction}

Breast cancer is the most common malignancy in women worldwide $(1,2)$. The etiology of breast cancer is complicated and the prognosis of patients is hard to predict. Therefore, identifying novel biomarkers to predict prognosis and determine the treatment method is important. Previous research into the etiology of breast cancer has focused on the role of the immunity $(3,4)$. The transcription factor PU.1 is a critical regulator of cellular communication in the immune system (5). PU.1 is one of the members of E-twenty six (ETS) transcription factor family and is encoded by the spleen focus forming virus proviral integration site 1 (SPII) gene in humans (6). PU.1 is able to activate gene expression during myeloid, erythroid and B-lymphoid cell development $(7,8)$. Furthermore, two isoforms of the human protein are produced by alternative splicing (9). Mice lacking PU.1 do not produce lymphocytes, myeloid cells or the progenitors for these cells $(9,10)$. High expression of PU.1 in hematopoietic progenitors directs myeloid development, and low expression directs B cell development (11).

Moreover, the loss of cellular communication caused by reduced PU.1 levels is able to lead to leukemia (5). Mice carrying hypomorphic SPI1 alleles that reduce PU.1 expression exhibit blockade of myeloid differentiation, leading to the development of acute myeloid leukemia (12). In classical Hodgkin lymphoma cells, PU.1 is a potent tumor suppressor, and the induction of PU.1 expression is a potential therapeutic option for patients with classical Hodgkin lymphoma (13). It has also been recently reported that minimal PU.1 reduction induces a preleukemic state and promotes development of acute myeloid leukemia (14). PU.1 reduces the transcriptional 
activity of the p53 tumor suppressor family and thus inhibits the activation of genes important for cell cycle regulation and apoptosis (15). It has also been reported that PU.1 functions as oncogene in Friend virus-induced erythroleukemia and as a tumor suppressor in acute myeloid leukemia (15). Therefore, these studies suggest that PU.1 may have an important role in tumor genesis and progression, and may be an attractive therapeutic target in cancer.

However to date, to the best of our knowledge, no studies have suggested the significance of PU.1 expression in solid tumors, including breast cancer. For the first time, to the best of our knowledge, the expression of PU.1 protein was detected by immunohistochemical (IHC) staining using a tissue microarray (TMA) and paraffin-embedded sections. In addition, the results were validated by western blotting using pair-matched breast samples. PU.1 expression in breast tissues from Tumor Cancer Genome Atlas (TCGA) database was also analyzed. The associations between PU.1 expression level and clinicopathological features, including overall survival (OS) of patients, were examined.

\section{Materials and methods}

Patients and tissue samples. The formalin-fixed paraffinembedded specimens with 80 invasive breast cancer samples and paired 50 control breast tissues used for IHC were collected from patients from the Department of Pathology at the First Affiliated Hospital of Harbin Medical University (Harbin, China) from 7 January 2015 to 20 January 2016. Breast tumor TMAs (HBre-Duc150Sur-01 and HBre-Duc090Sur-01) were obtained from Shanghai Outdo Biotech Co. (Shanghai, China). The array contains 150 cases of invasive ductal carcinoma. In parallel, 90 normal breast tissues from the regions around the tumor were included for control. However, only 60 samples were confirmed as normal breast tissues by pathologists. None of the patients received adjuvant chemotherapy, immunotherapy or radiotherapy prior to surgery. According to clinical requirement, estrogen receptor (ER), progesterone receptor (PR), human epidermal growth factor receptor 2 (Her-2), Ki67, p53, androgen receptor (AR) and epidermal growth factor receptor (EGFR) were also routinely stained for all invasive breast cancer patients. All tissue specimens and slides were examined by experienced pathologists. Clinical and pathological information was extracted from medical charts and pathology reports of the patients. Samples that exhibited nuclear staining for ER or PR in $>1 \%$ of the cells were considered as positive (16). Positive staining for Her-2 was defined on the basis of the percentage of tumor cells and the intensity of membrane staining. Her-2 was scored from 0 to $3+$ on the basis of the method recommended for the Dako Hercep test (Dako; Agilent Technologies, Inc., Santa Clara, CA, USA). Tumors were recognized as positive for Her-2 if immunostaining was scored as $3+$ or when the Her-2 fluorescence in situ hybridization amplification ratio was $>2.2$ (17). Positive thresholds for p53 and Ki-67 were 20 and $15 \%$ (18), respectively. AR was classified as positive or negative, with no scoring system used (19). For EGFR, positive membrane staining of $\geq 10 \%$ cells was defined as positive tumor expression (20). The Tumor-Node-Metastasis staging system of breast cancer cases was assessed according to the American Joint Committee on Cancer Staging Manual, 7th edition (21). The present study was approved by the Ethical Committee of the Third Affiliated Hospital of Harbin Medical University, Harbin, China. All patients provided written informed consent for participation in the present study.

Follow-up of TMA. All the breast cancer patients from TMA in the present study were followed-up periodically for survival analysis until mortality or until the study ended (July 2014). The median follow-up time among the 150 patients was 111 months, with a range of 4-162 months. Clinical records of the patients were obtained from the Shanghai Outdo Biotech Co.

Immunohistochemical staining. All tissue blocks were fixed in $4 \%$ formalin for $24 \mathrm{~h}$ at room temperature and were cut in a microtome to $4 \mu \mathrm{m}$. The tissue sections were dried at $60^{\circ} \mathrm{C}$ for $1 \mathrm{~h}$. The tissue sections were dewaxed in xylene and rehydrated through graded alcohol concentrations using standard procedures. Antigen retrieval was performed in citrate buffer (pH 6.0) and autoclaved at $121^{\circ} \mathrm{C}$ for $90 \mathrm{sec}$. Following washing in PBS (three washes with a duration of 3 min for each wash), the sections were blocked with goat serum (Wuhan Boster Biological Technology, Ltd., Wuhan, China) at room temperature for $30 \mathrm{~min}$. Then, each section was treated with PU.1 rabbit polyclonal antibodies (1:200; cat. no. sc-352; Santa Cruz Biotechnology, Inc., Dallas, TX, USA) at $4^{\circ} \mathrm{C}$ overnight. Following washing in PBS (three washes with $3 \mathrm{~min}$ for each wash), each section was incubated with Polink-1 HRP DAB Detection system and One-step Polymer Detection system for rabbit antibody (cat. no. PV-6001; OriGene Technologies, Inc., Beijing, China) at room temperature for $20 \mathrm{~min}$. Following washing in PBS (three washes with 3 min for each wash), the slides were counterstained with hematoxylin for $50 \mathrm{sec}$ at room temperature. For negative controls, the primary antibody was substituted with PBS. In line with the study by Cattoretti et al (22), human tonsil tissues (obtained from the Department of Otorhinolaryngology, The Second Affiliated Hospital of Harbin Medical University) were used as PU.1 positive controls (22).

Evaluation of IHC staining. Evaluation of PU.1 staining was performed with bright-field light microscopy independently by two experienced pathologists, who had no knowledge of the clinicopathological information. Staining of PU.1 protein was observed in the cytoplasm, and the tissues were divided into three groups according to expression level as follows: 0-24, $25-49$ and $\geq 50 \%$ positive staining of tumor cells. Expression was considered as positive, if $\geq 25 \%$ of the neoplastic cells were stained and as negative if $\leq 25 \%$ of the neoplastic cells were stained (23). Furthermore, cases with discrepancies were re-reviewed simultaneously by the two pathologists, and a senior pathologist until a consensus was reached.

Western blot analysis. Frozen tissue samples were homogenized in Radioimmunoprecipitation Assay buffer consisting of $1 \%$ protease inhibitor mixture. The mixture was centrifuged at $14,000 \mathrm{x}$ g for $15 \mathrm{~min}$ at $4^{\circ} \mathrm{C}$, and the supernatant was obtained. Total protein was quantified using the BCA Protein Assay kit 
(Beyotime Institute of Biotechnology, Shanghai, China), and $30 \mu \mathrm{g}$ protein per sample was separated by $12 \%$ SDS-PAGE and then transferred to a methanol-activated polyvinylidene difluoride membrane. Prior to immunodetection, the membranes were blocked with 5\% non-fat dried milk in TBST. The aforementioned PU.1 rabbit polyclonal antibody (1:200) was diluted in the buffer and incubated at $4^{\circ} \mathrm{C}$ overnight. Following subsequent washing with TBST, the membranes were incubated with secondary antibody [horseradish peroxidase-conjugated affinipure goat anti-rabbit $\operatorname{IgG}$ $(\mathrm{H}+\mathrm{L})$; 1:5,000; cat. no. ZB-2301; Origene Technologies, Inc.] for $1 \mathrm{~h}$ at room temperature. Mouse-anti- $\beta$-actin antibody was used as reference (GeneTex, Inc., Irvine, CA, USA). The experiment was repeated in triplicate. The bands were detected by enhanced chemiluminescence detection reagents (Applygen Technologies, Inc., Beijing, China).

Fluorescence in situ hybridization (FISH). FISH analysis was performed on paraffin-embedded sections at 4- $\mu \mathrm{m}$ thickness using the Vysis LSI HER2 Spectrum Orange and CEP17 Spectrum Green Dual Color DNA Probe kit (cat. no. 36-161060; Vysis PathVysion; Abbot Laboratories, Abbott Park, IL, USA) in line with the manufacturer's instructions. Pretreated procedure comprised the following steps: Incubation of sections in Hemo-De for $10 \mathrm{~min}$ at room temperature, (repeated twice), then deparaffinization, deproteinization and refixation. Then, according to the protocol, the sections were denatured and hybridized at $42^{\circ} \mathrm{C}$ overnight in a hybridization oven. Finally the sections were washed and counterstained with DAPI (Invitrogen; Thermo Fisher Scientific, Inc., Waltham, MA, USA). Scoring of Her-2 and CEP17 probe signals performed using a fluorescence microscope (BX51; Olympus Corporation, Tokyo, Japan). The slides were re-evaluated by two independent pathologists, and the invasive areas were identified. The pathologists assessed Her-2 status following the 2013 American Society of Clinical Oncology/College of American Pathologists recommendations (24).

Statistical analysis. All statistical analyses were performed by using SPSS software (version 17.0; SPSS, Inc., Chicago, IL, USA). The chi-square test was used to compare PU.1 expression between breast cancer and normal breast tissue groups. The association between the PU.1 protein and clinicopathologic parameters was also assessed using chi-square tests. Furthermore, the correlation between PU.1 expression and Her-2 status was assessed using Pearson's coefficient. For analysis of the follow-up data, the Kaplan-Meier method and log-rank test were used to estimate OS. The effects of different variables on survival were assessed using Cox regression in univariate and multivariate analyses. $\mathrm{P}<0.05$ was considered to indicate a statistically significant difference.

\section{Results}

Characteristics of patients. The clinical characteristics of the patients were listed in Table I. The median age of the patients was 52 years old (range, 23-83). Of all the patients with available clinical information $(\mathrm{n}=230)$, lymph node metastasis (LNM) was present in 122 patients $(122 / 201$;
Table I. Clinicopathological characteristics of patients with breast cancer.

Characteristics

Number of cases $(n=230)$

Age, years

Median 52

Range

Tumor size, $\mathrm{cm}$

$\leq 2$

62

$>2$

LNM

Negative

Positive

TNM stage

I-II

116

III

53

Histological grade

I-II

III

38

ER

Negative

105

Positive

118

PR

Negative $\quad 121$

Positive 99

Her-2

Negative $\quad 128$

Positive 98

Ki67

Negative $\quad 91$

Positive 119

p53

Negative 118

Positive $\quad 85$

AR

Negative $\quad 70$

Positive 75

EGFR

Negative $\quad 122$

Positive $\quad 72$

Subtype

Luminal A $\quad 43$

Luminal B $\quad 77$

Her-2 49

Basal-like $\quad 46$

Some patient information is missing, meaning not all characteristics add up to $n=230$. AR, androgen receptor; EGFR, epidermal growth factor receptor; ER, estrogen receptor; Her-2, human epidermal growth factor receptor 2; LNM, lymph node metastasis; PR, progesterone receptor; TNM, Tumor-Node-Metastasis.

60.7\%), and absent in 79 patients $(79 / 201 ; 39.3 \%)$. A total of $116(116 / 169 ; 68.6 \%)$ patients were classified at TNM 
Table II. Expression of PU.1 in normal breast epithelial and breast cancer tissues.

\begin{tabular}{|c|c|c|c|c|}
\hline \multirow[b]{2}{*}{ Groups } & \multirow[b]{2}{*}{$\mathrm{n}$} & \multicolumn{2}{|c|}{$\begin{array}{c}\text { PU.1 expression, } \\
\mathrm{n}(\%)\end{array}$} & \multirow[b]{2}{*}{ P-value } \\
\hline & & Negative & Positive & \\
\hline $\begin{array}{l}\text { Normal } \\
\text { breast tissue }\end{array}$ & 110 & $79(71.8)$ & $31(28.2)$ & $2.63 \times 10^{-8}$ \\
\hline Breast cancer & 230 & 91 (39.6) & $139(60.4)$ & \\
\hline
\end{tabular}

A

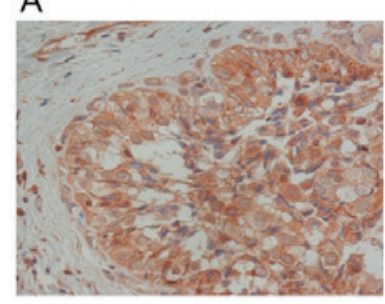

B
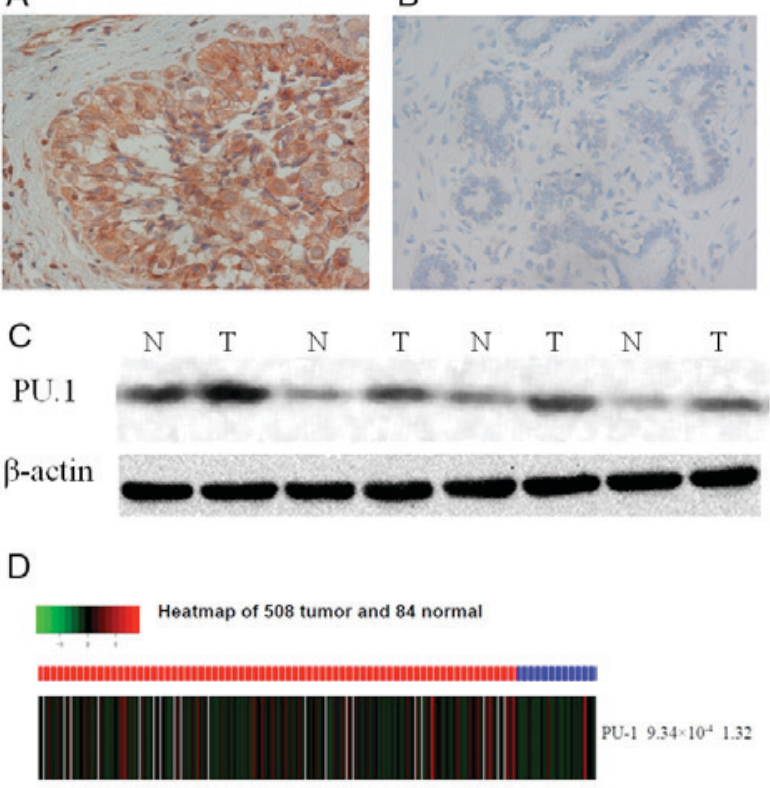

Figure 1. Detection of PU.1 protein expression. (A) Positive expression of PU.1 in breast cancer tissues as detected by IHC (magnification, $\mathrm{x} 400$ ). (B) Negative expression of PU.1 in breast cancer tissues as detected by IHC (magnification, x400). (C) Western blotting indicated increased PU.1 expression in breast cancer tissues compared with normal tissues. $\beta$-actin was used as an internal control. (D) Heat Map indicated increased PU.1 expression in breast cancer tissues from the Tumor Cancer Genome Atlas data portal. $\mathrm{T}$, tumor; $\mathrm{N}$, normal.

stages I and II, and $53(53 / 169 ; 31.4 \%)$ patients were at stage III. A total of $180(180 / 218 ; 82.6 \%)$ patients were classified as histological grades I and II, and the grade III were $38(38 / 218 ; 17.4 \%)$.

High expression of PU.1 protein in breast cancer tissues. In the present study, the expression of PU.1 protein was detected in breast cancer and normal breast tissues by IHC and western blotting. There was a markedly higher level of PU.1 expression in breast cancer tissues compared with normal tissues (Fig. 1A and B). The IHC results indicated that PU.1 expression was detected in the cytoplasm of invasive breast cancer cells (Fig. 1A and B). Of the 230 breast cancer specimens, positive PU.1 expression was detected in 139 (139/230; 60.4\%) samples, and positive PU.1 expression was only detected in 31 out of $110(28.2 \%)$ paired normal tissues $\left(\mathrm{P}=2.63 \times 10^{-8}\right.$; Table II). Markedly increased expression of PU.1 was also
Table III. Associations between PU.1 expression and clinicopathological factors of patients with breast cancer.

\begin{tabular}{|c|c|c|c|c|}
\hline \multirow[b]{2}{*}{ Variables } & \multirow[b]{2}{*}{$\mathrm{n}$} & \multicolumn{2}{|c|}{ PU.1 expression } & \multirow[b]{2}{*}{ P-value } \\
\hline & & Negative & Positive & \\
\hline \multicolumn{5}{|l|}{ Age, years } \\
\hline$\leq 50$ & 108 & $49(45.4)$ & $59(54.6)$ & 0.068 \\
\hline$>50$ & 122 & $41(33.6)$ & $81(66.4)$ & \\
\hline \multicolumn{5}{|c|}{ Tumor size, cm } \\
\hline$\leq 2$ & 62 & $21(33.9)$ & $41(66.1)$ & 0.473 \\
\hline$>2$ & 143 & $56(39.2)$ & 87 (60.8) & \\
\hline \multicolumn{5}{|l|}{ LNM } \\
\hline Negative & 79 & $30(38.0)$ & $49(62.0)$ & 0.938 \\
\hline Positive & 122 & 47 (38.5) & 75 (61.5) & \\
\hline \multicolumn{5}{|l|}{ TNM stage } \\
\hline $\mathrm{I}-\mathrm{II}$ & 116 & $48(41.4)$ & 68 (58.6) & 0.164 \\
\hline III & 53 & $16(30.2)$ & 37 (69.8) & \\
\hline \multicolumn{5}{|c|}{ Histological grade } \\
\hline $\mathrm{I}-\mathrm{II}$ & 180 & $70(38.9)$ & $110(61.1)$ & 0.946 \\
\hline III & 38 & $15(39.5)$ & $23(60.5)$ & \\
\hline \multicolumn{5}{|l|}{ ER status } \\
\hline Negative & 105 & $38(36.2)$ & 67 (63.8) & 0.231 \\
\hline Positive & 118 & $52(44.1)$ & 66 (55.9) & \\
\hline \multicolumn{5}{|l|}{ PR status } \\
\hline Negative & 121 & $43(35.5)$ & 78 (64.5) & 0.232 \\
\hline Positive & 99 & $43(43.4)$ & $56(56.6)$ & \\
\hline
\end{tabular}

Her-2 status

$\begin{array}{lrccc}\text { Negative } & 128 & 85(66.4) & 43(33.6) & 2.033 \times 10^{-21} \\ \text { Positive } & 98 & 4(4.1) & 94(95.9) & \\ \text { Ki67 status } & & & & \\ \quad \text { Negative } & 91 & 40(44.0) & 51(56.0) & 0.161 \\ \text { Positive } & 119 & 41(34.5) & 78(65.5) & \\ \text { p53 status } & & & & \\ \text { Negative } & 118 & 44(37.3) & 74(62.7) & 0.695 \\ \text { Positive } & 85 & 34(40.0) & 51(60.0) & \\ \text { AR } & & & & \\ \text { Negative } & 70 & 32(45.7) & 38(54.3) & 0.027 \\ \text { Positive } & 75 & 21(28.0) & 54(72.0) & \\ \text { EGFR } & & & & \\ \text { Negative } & 122 & 47(38.5) & 75(61.5) & 0.887 \\ \text { Positive } & 72 & 27(37.5) & 45(62.5) & \\ \text { Molecular subtypes } & & & & \\ \text { Luminal A } & 43 & 28(65.1) & 15(34.9) & 3.508 \times 10^{-11} \\ \text { Luminal B } & 77 & 23(29.9) & 54(70.1) & \\ \text { Her-2 } & 49 & 2(4.1) & 47(95.9) & \\ \text { Basal-like } & 46 & 29(63.0) & 17(37.0) & \end{array}$

AR, androgen receptor; EGFR, epidermal growth factor receptor; ER, estrogen receptor; Her-2, human epidermal growth factor receptor 2; LNM, lymph node metastasis; PR, progesterone receptor; TNM, Tumor-Node-Metastasis. 
A

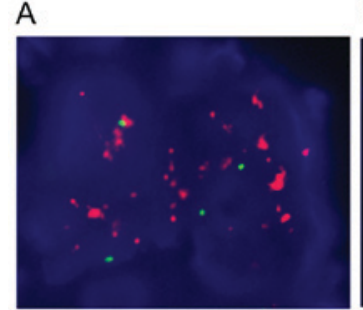

D

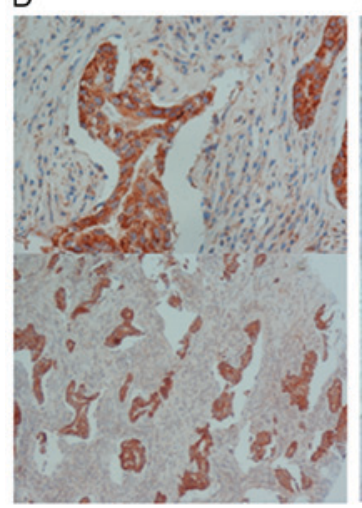

B

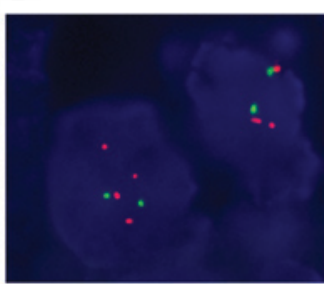

E

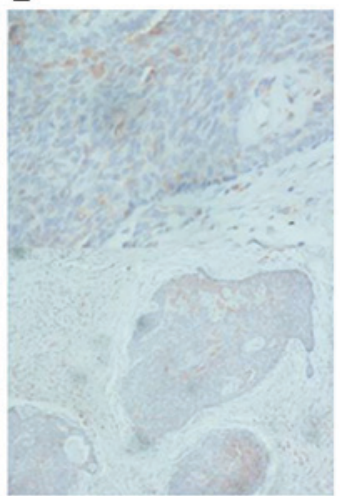

C

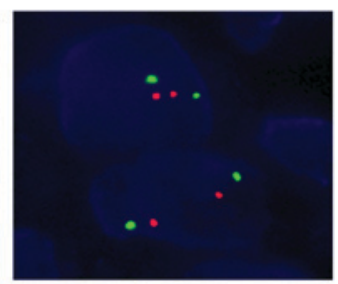

$\mathrm{F}$

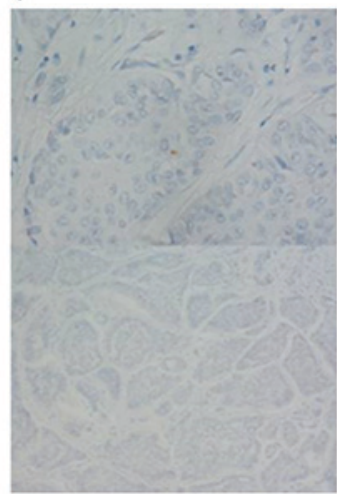

Figure 2. Her-2 gene status and PU.1 expression in breast cancer tissues as identified by fluorescence in situ hybridization (magnification, x600) and IHC [magnification, x400 (upper panels) and x100 (bottom panels)]. (A) Positive and (B) negative Her-2 gene status with a score $\geq 2$ by IHC. (C) Negative Her-2 gene status scoring <2 by IHC. (D) positive PU.1 expression. (E) Negative PU.1 expression in a Her-2-negative sample by FISH but assessed positive by IHC. (F) Negative PU.1 expression in a Her-2 negative specimen, assessed by IHC. Her-2, human epidermal growth factor receptor 2; IHC, immunohistochemistry.

detected in breast cancer tissues compared with the matched normal tissues by western blotting (Fig. 1C). Consistent with these results, PU.1 expression was observed to be significantly higher in breast cancer tissues compared with non-tumor tissues from the TCGA database $\left(\mathrm{P}=9.34 \times 10^{-4}\right)(508$ breast tumor samples and 83 adjacent non-tumor breast tissues) as shown in heat map (Fig. 1D).

Associations between PU.1 protein immunoreactivity and clinicopathological parameters. The association between PU.1 protein expression and clinicopathological variables of the 230 breast cancer specimens was analyzed (Table III). Increased expression of PU.1 was associated with Her-2 expression, AR expression and molecular subtypes (Table III). There were 94 out of 98 patients $(95.9 \%)$ who were Her-2 positive compared with 43 out of 128 (33.6\%) who were Her-2 negative. In addition, there was a significantly higher incidence of PU.1 expression in these patients that were Her-2 positive compared with patients who were Her- 2 negative $\left(\mathrm{P}=2.03 \times 10^{-21}\right.$; Table III). Pearson's coefficient analysis suggested that PU.1 expression was positively correlated with Her-2 status $(R=0.632$, $\left.\mathrm{P}=7.31 \times 10^{-26}\right)$.

FISH was also performed to confirm the positive correlation of Her-2 gene status with PU.1 expression (Fig. 2). Moreover, $54.3 \%$ (38/70) of the cases in the AR-negative group were positive for PU.1, and $72.0 \%$ (54/75) of the cases in the AR-positive group were positive for PU.1 ( $\mathrm{P}=0.027$; Table III). The expression of PU.1 was associated with breast cancer subtypes, and the rate of positive PU.1 expression was higher in cases positive for Her-2 status $\left(\mathrm{P}=3.51 \times 10^{-11}\right)$. No significant association was observed between PU.1 expression and other clinicopathological parameters, including age $(\mathrm{P}=0.068)$, tumor size $(\mathrm{P}=0.473)$, lymph node metastasis $(\mathrm{LNM})(\mathrm{P}=0.938)$, TNM

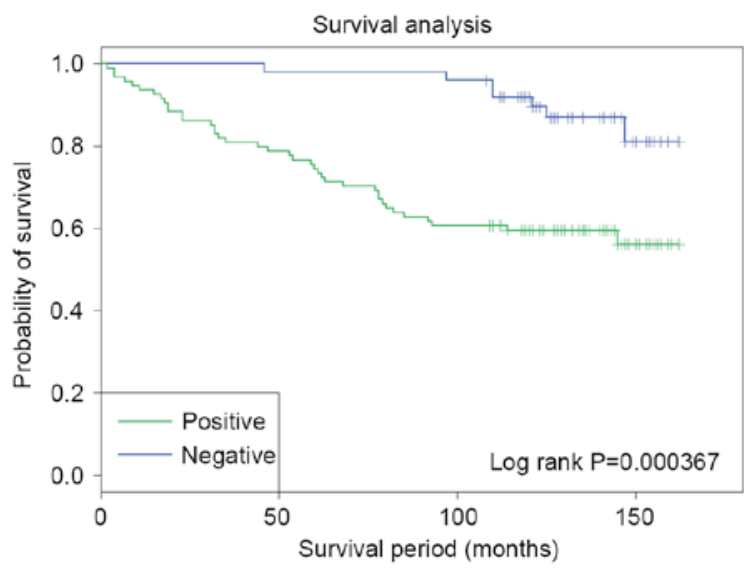

Figure 3. Kaplan-Meier analysis for 10-year overall survival based on PU.1 expression in 150 tissue microarray breast cancer samples. PU.1 expression was considered as positive, if $\geq 25 \%$ of the neoplastic cells were stained and as negative if $<25 \%$ of the neoplastic cells were stained.

stage $(\mathrm{P}=0.164)$, histological grade $(\mathrm{P}=0.946)$ and status of $\mathrm{ER}$ $(\mathrm{P}=0.231), \mathrm{PR}(\mathrm{P}=0.232), \mathrm{p} 53(\mathrm{P}=0.695), \mathrm{Ki} 67(\mathrm{P}=0.161)$ and EGFR ( $\mathrm{P}=0.887)$ (Table III).

Prognostic significance of PU.1 expression in breast cancer. To further validate the potential clinical significance of the PU.1 overexpression, the association between PU.1 protein expression and OS was evaluated in 150 TMA breast cancer samples with 10-year follow-up information from patients. Kaplan Meier survival analysis and log-rank test were used. As shown in Fig. 3, among the 150 patients, patients with PU.1 positive expression exhibited significantly poorer outcome in terms of OS compared 
with patients with negative PU.1 expression $\left(\mathrm{P}=3.67 \times 10^{-4}\right.$; log-rank test).

Univariate and multivariate survival analyses were also used to evaluate the association between PU.1 expression and clinicopathological characteristics on prognosis (Table IV). Univariate analyses of OS using Cox regression analysis identified TNM stage $(\mathrm{P}=0.007)$, Her-2 expression $(\mathrm{P}=0.005)$ and PU.1 expression $(\mathrm{P}=0.001)$ as significant prognostic predictors. No other parameters were determined to have statistically significant associations with prognosis. Using multivariate analysis, it was identified that only TNM $(\mathrm{P}=0.018)$ and PU.1 expression $(\mathrm{P}=0.034)$ were independent prognostic factors (Table IV).

\section{Discussion}

Studies have suggested that chronic or recurrent inflammation may have a role in the development of breast cancer $(4,25)$. The transcription factor PU.1 is highly expressed in immune cells and exerts key roles in several steps of the inflammatory pathway (26). Recently Kueh et al (27) reported that positive feedback between PU.1 and cell cycle can control myeloid differentiation.

In the present study, to the best of our knowledge, the expression of PU.1 protein was analyzed by IHC for the first time. High PU.1 expression was detected in 139 out of 230 (60.4\%) breast cancer specimens, while 31 out of 110 (28.2\%) of normal breast tissues exhibited high PU.1 expression.

Although there might be differences in PU.1 expression between Asian and American populations, the results are consistent with analysis of TCGA data from an American population, which indicates higher PU.1 expression level in breast cancer tissues compared with normal breast tissues. The results in the present study suggest that PU.1 may have an oncogenic role, which contributes to the development of breast cancer. However, the precise mechanisms underlying the regulation of PU.1 in breast carcinogenesis was unclear.

To date, there have been a number of studies which provided clues for the mechanisms of PU.1. Zhou et al (28) suggested that PU.1 affects proliferation of the human acute myeloid leukemia U937 cell line by directly regulating MEIS1 promoter through a conserved binding motif and Tschan et al (15) reported the binding of PU.1 to the p53 family, which impairs its transcriptional activity.

The associations between PU.1 expression with clinicopathological parameters in breast cancer patients were also examined. Overall, the findings indicate positive association of PU.1 expression with AR, Her-2 and molecular subtype. However, there was no statistically significant association detected between PU.1 expression and p53 status. Furthermore, positive correlation between Her-2 status and PU.1 expression was detected by Pearson's coefficient analysis in the present study.

It has been previously reported that Her-2 status was associated with malignancy and poor prognosis in breast cancer $(29,30)$. In the present study, high PU.1 expression was correlated with poorer OS in patients with breast cancer. These results suggest that PU.1 expression may be used as a marker to identify subsets of breast cancer patients with high malignancy and poor prognosis. Therefore, further investigation is required
Table IV. Prognostic factors in the Cox proportional hazards model.

A, Univariate analysis

\begin{tabular}{|c|c|c|c|}
\hline Variables & Risk ratio & $95 \% \mathrm{CI}$ & P-value \\
\hline \multicolumn{4}{|l|}{ Age, years } \\
\hline$\leq 50$ vs. $>50$ & 0.697 & $0.385-1.260$ & 0.232 \\
\hline \multicolumn{4}{|l|}{ Tumor size, $\mathrm{cm}$} \\
\hline$\leq 2$ vs. $>2$ & 0.770 & $0.382-1.552$ & 0.465 \\
\hline \multicolumn{4}{|l|}{ LNM } \\
\hline Negative vs. positive & 0.734 & $0.388-1.390$ & 0.342 \\
\hline \multicolumn{4}{|l|}{ TNM stage } \\
\hline I and II vs. III & 0.444 & $0.248-0.798$ & 0.007 \\
\hline \multicolumn{4}{|l|}{ Histological grade } \\
\hline I vs. II and III & 0.825 & $0.417-1.631$ & 0.580 \\
\hline \multicolumn{4}{|l|}{ ER status } \\
\hline Negative vs. positive & 1.746 & $0.921-3.310$ & 0.880 \\
\hline \multicolumn{4}{|l|}{ PR status } \\
\hline Negative vs. positive & 0.331 & $0.702-2.522$ & 0.381 \\
\hline \multicolumn{4}{|l|}{ Her-2 status } \\
\hline Negative vs. positive & 0.398 & $0.211-0.752$ & 0.005 \\
\hline \multicolumn{4}{|l|}{ Ki67 status } \\
\hline Negative vs. positive & 1.011 & $0.555-1.841$ & 0.972 \\
\hline \multicolumn{4}{|l|}{ p53 status } \\
\hline Negative vs. positive & 0.999 & $0.537-1.856$ & 0.997 \\
\hline \multicolumn{4}{|l|}{ AR } \\
\hline Negative vs. positive & 0.907 & $0.498-1.653$ & 0.750 \\
\hline \multicolumn{4}{|l|}{ EGFR } \\
\hline Negative vs. positive & 0.609 & $0.332-1.118$ & 0.110 \\
\hline \multicolumn{4}{|l|}{ PU.1 } \\
\hline Negative vs. positive & 0.242 & $0.108-0.543$ & 0.001 \\
\hline
\end{tabular}

B, Multivariate analysis

\begin{tabular}{lccc}
\hline Variable & Risk ratio & $95 \%$ CI & P-value \\
\hline $\begin{array}{l}\text { TNM stage } \\
\text { I and II vs. III }\end{array}$ & 0.480 & $0.262-0.879$ & 0.018 \\
$\begin{array}{l}\text { PU.1 } \\
\text { Negative vs. positive }\end{array}$ & 0.265 & $0.118-0.598$ & 0.034 \\
\hline
\end{tabular}

$\mathrm{AR}$, androgen receptor; CI, confidence interval; EGFR, epidermal growth factor receptor; ER, estrogen receptor; Her-2, human epidermal growth factor receptor 2; LNM, lymph node metastasis; $\mathrm{PR}$, progesterone receptor; TNM, Tumor-Node-Metastasis.

to elucidate whether combined detection of PU.1 expression with Her-2 status would be more valuable in improving the prediction of prognosis of patients with breast cancer. Moreover, univariate and multivariate Cox regression analysis revealed that PU.1 expression level and TNM stage were independent prognostic factors for OS. 
In future studies, the present authors will examine the microRNA regulatory networks and transcription factor-DNA networks for PU.1 and investigate the mechanisms involved in breast cancer or subtype-specific breast cancer based on the finding of positive correlation between PU.1 expression and Her-2 status identified in the present study.

In conclusion, it was identified that PU.1 expression may be a valuable prognostic factor in patients with breast cancer. The findings also indicated significant associations between PU.1 expression and Her-2 and AR status as well as molecular subtypes in breast cancer. These results suggested that PU.1 is a potentially important target for the prediction of prognosis. However, due to the limited sample size, these findings remain to be confirmed by a larger study. More detailed understanding of the signaling pathways regulated by PU.1 may ultimately lead to ideas for novel molecular targeted therapies for breast cancer.

\section{Acknowledgements}

The present study was funded by grants from the National Natural Science Foundation of China (grant no. 81202074), the Natural Science Foundation of Heilongjiang (grant no. QC2016118) and the Foundation for Harbin Science and Technology Innovation Talents [grant nos. 2016RAXYJ107 (to L.W.) and 2017LCZX74 (to J.L)].

\section{References}

1. Stagl JM, Bouchard LC, Lechner SC, Blomberg BB Gudenkauf LM, Jutagir DR, Glück S, Derhagopian RP, Carver CS and Antoni MH: Long-term psychological benefits of cognitive-behavioral stress management for women with breast cancer: 11-year follow-up of a randomized controlled trial. Cancer 121: 1873-1881, 2015.

2. DeSantis C, Ma J, Bryan L and Jemal A: Breast cancer statistics, 2013. CA Cancer J Clin 64: 52-62, 2014.

3. Malladi S, Macalinao DG, Jin X, He L, Basnet H, Zou Y, de Stanchina E and Massague J: Metastatic latency and immune evasion through autocrine inhibition of WNT. Cell 165: 45-60, 2016

4. Grivennikov SI, Greten FR and Karin M: Immunity, inflammation, and cancer. Cell 140: 883-899, 2010.

5. Turkistany SA and DeKoter RP: The transcription factor PU.1 is a critical regulator of cellular communication in the immune system. Arch Immunol Ther Exp (Warsz) 59: 431-440, 2011.

6. Verbiest T, Bouffler S, Nutt SL and Badie C: PU.1 downregulation in murine radiation-induced acute myeloid leukaemia (AML) From molecular mechanism to human AML. Carcinogenesis 36 413-419, 2015

7. Chen HM, Zhang P, Voso MT, Hohaus S, Gonzalez DA, Glass CK, Zhang DE and Tenen DG: Neutrophils and monocytes express high levels of PU.1 (Spi-1) but not Spi-B. Blood 85: 2918-2928, 1995.

8. Cantor AB and Orkin SH: Hematopoietic development: A balancing act. Curr Opin Genet Dev 11: 513-519, 2001.

9. McKercher SR, Torbett BE, Anderson KL, Henkel GW, Vestal DJ, Baribault H, Klemsz M, Feeney AJ, Wu GE, Paige CJ, et al: Targeted disruption of the PU.1 gene results in multiple hematopoietic abnormalities. EMBO J 15: 5647-5658, 1996.

10. Scott EW, Simon MC, Anastasi J and Singh H: Requirement of transcription factor PU.1 in the development of multiple hematopoietic lineages. Science 265: 1573-1577, 1994.

11. DeKoter RP and Singh H: Regulation of B lymphocyte and macrophage development by graded expression of PU.1. Science 288: 1439-1441, 2000.

12. Rosenbauer F, Wagner K, Kutok JL, Iwasaki H, Le Beau MM, Okuno Y, Akashi K, Fiering S and Tenen DG: Acute myeloid leukemia induced by graded reduction of a lineage-specific transcription factor, PU.1. Nat Genet 36: 624-630, 2004.
13. Yuki H, Ueno S, Tatetsu H, Niiro H, Iino T, Endo S, Kawano Y, Komohara Y, Takeya M, Hata H, et al: PU.1 is a potent tumor suppressor in classical Hodgkin lymphoma cells. Blood 121: 962-970, 2013.

14. Will B, Vogler TO, Narayanagari S, Bartholdy B, Todorova TI, da Silva Ferreira M, Chen J, Yu Y, Mayer J, Barreyro L, et al: Minimal PU.1 reduction induces a preleukemic state and promotes development of acute myeloid leukemia. Nat Med 21: 1172-1181, 2015.

15. Tschan MP, Reddy VA, Ress A, Arvidsson G, Fey MF and Torbett BE: PU.1 binding to the p53 family of tumor suppressors impairs their transcriptional activity. Oncogene 27: 3489-3493, 2008.

16. Hammond ME, Hayes DF, Dowsett M, Allred DC, Hagerty KL, Badve S, Fitzgibbons PL, Francis G, Goldstein NS, Hayes M, et al: American society of clinical oncology/college of American pathologists guideline recommendations for immunohistochemical testing of estrogen and progesterone receptors in breast cancer. J Clin Oncol 28: 2784-2795, 2010

17. Wolff AC, Hammond ME, Hicks DG, Dowsett $M$, McShane LM, Allison KH, Allred DC, Bartlett JM, Bilous M, Fitzgibbons $\mathrm{P}$, et al: Recommendations for human epidermal growth factor receptor 2 testing in breast cancer: American society of clinical oncology/college of American pathologists clinical practice guideline update. Arch Pathol Lab Med 138: 241-256, 2014.

18. Yerushalmi R, Woods R, Ravdin PM, Hayes MM and Gelmon KA: Ki67 in breast cancer: Prognostic and predictive potential. Lancet Oncol 11: 174-183, 2010.

19. Gonzalez-Sistal A, Baltasar-Sanchez A, Menendez P, Arias JI and Ruibal A: Breastfeeding and immunohistochemical expression of ki-67, p53 and BCL2 in infiltrating lobular breast carcinoma. PloS One 11: e0151093, 2016

20. Agboola AO, Banjo AA, Anunobi CC, Salami B, Agboola MD Musa AA, Nolan CC, Rakha EA, Ellis IO and Green AR: Cell proliferation (KI-67) expression is associated with poorer prognosis in Nigerian compared to British breast cancer women. ISRN Oncol 2013: 675051, 2013.

21. Edge SB and Compton CC: The American joint committee on cancer: The 7th edition of the AJCC cancer staging manual and the future of TNM. Ann Surg Oncol 17: 1471-1474, 2010

22. Cattoretti G, Shaknovich R, Smith PM, Jack HM, Murty VV and Alobeid B: Stages of germinal center transit are defined by B cell transcription factor coexpression and relative abundance. J Immunol 177: 6930-6939, 2006.

23. Hoefnagel JJ, Mulder MM, Dreef E, Jansen PM, Pals ST, Meijer CJ, Willemze R and Vermeer MH: Expression of B-cell transcription factors in primary cutaneous B-cell lymphoma. Mod Pathol 19: 1270-1276, 2006.

24. Wolff AC, Hammond ME, Hicks DG, Dowsett M, McShane LM, Allison KH, Allred DC, Bartlett JM, Bilous M, Fitzgibbons $\mathrm{P}$, et al: Recommendations for human epidermal growth factor receptor 2 testing in breast cancer: American society of clinical oncology/college of American pathologists clinical practice guideline update. J Clin Oncol 31: 3997-4013, 2013.

25. Cole SW: Chronic inflammation and breast cancer recurrence. J Clin Oncol 27: 3418-3419, 2009.

26. Chang HC, Sehra S, Goswami R, Yao W, Yu Q, Stritesky GL, Jabeen R, McKinley C, Ahyi AN, Han L, et al: The transcription factor PU.1 is required for the development of IL-9-producing $\mathrm{T}$ cells and allergic inflammation. Nat Immunol 11: 527-534, 2010.

27. Kueh HY, Champhekar A, Nutt SL, Elowitz MB and Rothenberg EV: Positive feedback between PU.1 and the cell cycle controls myeloid differentiation. Science 341: 670-673, 2013.

28. Zhou J, Zhang X, Wang $Y$ and Guan Y: PU.1 affects proliferation of the human acute myeloid leukemia U937 cell line by directly regulating MEIS1. Oncol Lett 10: 1912-1918, 2015.

29. Chou S, Khan T, Mahajan H and Pathmanathan N: Predicting discordant HER2 results in ipsilateral synchronous invasive breast carcinomas: Experience from a single institution. Pathology 47: 637-640, 2015.

30. Yarden Y: Biology of HER 2 and its importance in breast cancer. Oncology 61 (Suppl 2): S1-S13, 2001. 